Ummahan Yücel, İlkay Ünal, Tuğçe Özdemir, Merve Koyuncu, Nihal Çakmak Ege University, İzmir-Turkey

mmahan.yucel@ege.edu.tr; ilkay.unal@ege.edu.tr; tugce.2604@gmail.com; evremkoyuncu@gmail.com; nihalcakmak.97@hotmail.com

\begin{tabular}{l|l|l}
\hline DOI & \multicolumn{2}{|l}{$\mathrm{http}: / / \mathrm{dx} . \mathrm{doi} .0 \mathrm{rg} / 10.12739 / \mathrm{NWS} .2018 .13 .4 .1 \mathrm{~B} 0056$} \\
\hline \multirow{3}{*}{ ORCID ID } & $0000-0003-3531-8644$ & $0000-0001-8976-0003$ \\
\cline { 2 - 3 } & $0000-0002-5053-3476$ & $0000-0003-2813-4986$ \\
\cline { 2 - 3 } & $0000-0002-8132-9750$ \\
\hline
\end{tabular}

\title{
EBELİK ÖĞRENCİLERİNIN PROFESYONEL DEĞER ALGILARININ BELİRLENMESİ
}

Öz

Bu çalışma, ebelik öğrencilerinin profesyonel değer algılarını ve etkileyen bazı faktörlerini incelenmek amacı ile yapılmıştır. Kesitselanalitik tipteki araştırmaya 324 ebelik öğrencisi katılmıştır. Veriler 2017 yılında kişisel bilgi formu ve "Ebelerin Profesyonel Değerleri Ölçeği (EPDÖ)" ile toplanmıştır. EPDÖ'den alınan bireyin ölçek puanı (min.20max.100) arttıkça profesyonel değer algısı yükselmektedir. Veriler, SPPS 16.0 programında ortalama, t testi ve varyans testi ile analiz edilmiştir.

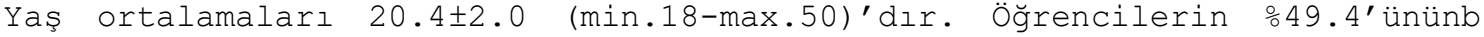
ölümü kendi isteği ile seçtiği ve o63.0'ünün mesleği kendilerine uygun bulduğu belirlenmiştir. Öğrencilerin ölçek puan ortalamaları $87.2 \pm 1.0$ (min.60-max.100)'dir. Eğitime başladıktan sonra mesleğe karşı olumlu görüşe sahip olan, ikinci ve dördüncü sınıfta okuyan, herhangi bir sağlık kurumunda, doğumhanede ve aile sağlığı merkezinde uygulamaya çıkan öğrencilerin profesyonel değer algıları yüksek saptanmıştır $(p<0.05)$. Sınıf düzeyi, eğitimden sonraki mesleki düşünce, herhangi bir sağlık kurumunda, doğumhanede ve aile sağlığı merkezinde uygulamaya çıkma durumunun, öğrencilerin profesyonel değer algılarını arttırdığı görülmüştür.

Anahtar Kelimeler: Ebelik, Meslek, Öğrenci, Profesyonel Değerler, Ölçek

\section{DETERMINATION OF PROFESSIONAL VALUE PERCEPTIONS OF MIDWIFERY STUDENTS}

\section{ABSTRACT}

This study was conducted with the aim of examining the Professional values perceptions of the midwifery students and some of the influencing factors. 324 midwifery students participated in the cross-analytical type survey. The data were collected in 2017 with the personal information form and "Midwifery Professional Values Scale (EPDÖ)". Professional value perception increases as the scale score (min.20-max.100) of the individual taken from EMRA increases. The data were analyzed by mean, t-test and variance test in the SPSS 16.0. The average age of the students' $20.4 \pm 2.0$ (min.18-max.50). It has been determined that 49.4\% of the students choose the department voluntarily and $63.0 \%$ of them find their profession. The

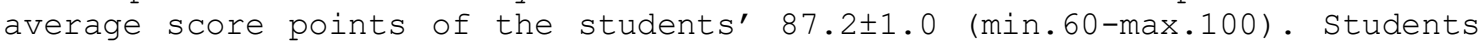
who have a positive opinion on the profession after their education have a high level of Professional perception of the students who study in the second and the fourth year, in any health institution, maternity ward and family health center $(\mathrm{p}<0.05)$. It's the view that class level, posttraining occupational thinking, practice at any health institution, maternity ward and family health center, increase the students' perception of Professional values.

Keywords: Midwifery, Profession, Student, Professional Values, Scale How to Cite:

Yücel. U., Ünal, İ., Özdemir, T., Koyuncu, M. ve Çakmak, N., (2018). Ebelik Öğrencilerinin Profesyonel Değer Algılarının Belirlenmesi, Medical Sciences (NWSAMS), $13(4)$ : 95-105, DOI: $10.12739 /$ NWSA.2018.13.4.1B0056. 


\section{GÍRIŞ (INTRODUCTION)}

Mesleki profesyonellik, mesleğin standartlarının oluşturulmasına ve kaliteli bakım sunulmasına katkı sağlar. Mesleğe özgü kimlik oluşumu, ebeleri diğer sağlık meslek üyelerinden ayırt etmede, meslek üyelerini kendilerini tanımalarında ve iş birliği yaptığı diğer meslek üyeleri ile iletişim kurmada önemli bir yol göstericidir [1 ve 2]. Profesyonel ebelik değerlerinin kazanılması ebelik eğitimi ile başlar [3]. Ebelik mesleği, toplum sağlığı sorunları ile mücadele etmede ve toplum sağlığını geliştirme çabalarında önemli bir role sahiptir [4]. Özellikle "21. Yüzyılda Herkes İçin Sağlık Hedefleri"nden "Yaşama Sağlıklı Başlanması Hedefi"nin gerçekleştirilmesinde önemli bir yeri olan gebelik, doğum ve doğum sonrası hizmetlerinin sunulmasında, ebelik mesleğinin anahtar rolü vurgulanmaktadır [5]. Bu ve benzeri sağlığı geliştirmeye yönelik hedeflerine ulaşmada sağlık hizmetlerinin niteliği ön plana çıkmaktadır. Nitelikli hizmetin ön koşullarından biri de mesleki profesyonelliktir.

\section{2. ÇALIŞMANIN ÖNEMI (RESEARCH SIGNIFICANCE)}

Meslekte profesyonellik, tüm meslek üyelerinde olması istenen ve beklenen bir özelliktir [6]. Profesyonelliğin temeli mesleğe adım atılan öğrencilik yıllarında başlar, alınan eğitim ile sürekli gelişir [3]. Ebelik eğitimi, teorik ve uygulama olmak üzere birbirini tamamlayan iki temel bölümden oluşur [7]. Ebelik öğrencilerinin, hem teorik hem de uygulama eğitimi almaya başladıkları andan itibaren mesleki profesyonelliklerini geliştirmeleri, topluma nitelikli bakım vermeleri açısından önemlidir. Bu araştırma ebelik öğrencilerinin profesyonel değer algılarını belirlemek amacıyla yapılmıştır.

\section{MATERYAL VE METOD (MATERIAL AND METHODS)}

Araştırma kesitsel analitik türde bir araştırmadır. Araştırmanın evrenini, Ege Üniversitesi Sağlık Bilimleri Fakültesi ve İzmir Atatürk Sağlık Yüksekokulu Ebelik Bölümü'nde 2017-2018 Eğitim-Öğretim döneminde öğrenim gören birinci ( $n=103)$, ikinci ( $n=118)$, üçüncü $(n=85)$ ve dördüncü (n=96) sınıf olmak üzere toplam 402 öğrenci oluşturmuştur. Evrenin tümünün örnekleme alınması planlanmış, çalışmaya katılmayı kabul eden 324 öğrenci ( 80.5$)$ çalışma kapsamına alınmıştır. Çalışma başlamadan önce, Meydan ve Kaya (2018)'dan e-mail yoluyla ölçek kullanım izni, Ege Üniversitesi Sağlık Bilimleri Fakültesi Bilimsel Araştırma Komisyonu tarafından etik kurul onayı (Tarih:02.03.2018, Sayı:63804) ve araştırmanın yürütülmesi için kurumdan yazılı izinler alınmıştır. Araştırma verileri 15 maddeden oluşan "Kişisel Bilgi Formu" ve "Meydan ve ark. (2018) tarafından geliştirilen Ebelerin Profesyonel Değerleri Ölçeği (EPDÖ)" ile toplanmıştır.

- Kişisel Bilgi Formu: Araştırmacllar tarafından geliştirilen kişisel bilgi formunda; öğrencinin yaşı, sınıfı, mezun olduğu lise, anne ve babanın eğitim durumu, bölümü tercih sırası, bölümü isteme durumu, ebelik mesleğini seçme nedeni, eğitimden önce ve sonra ebelik mesleğine ait düşünceleri ile ilgili bilgilere yer verilmiştir.

- Ebelerin Profesyonel Değerleri ölçeği (EPDÖ): EPDÖ, ebelerin profesyonel değerlerini belirlemek amacıyla Meydan ve ark.(2018) tarafından Uluslararası Ebelik Konfederasyonu (ICM) etik kodlarında rehber alınarak geliştirilmiştir. EPDÖ 5'li likert tipinde ("önemli değil" yanıtı "1", "biraz önemli" yanıtı "2", "önemli" yanıtı "3", "çok önemli" yanıtı "4" ve "son derece önemli" yanıtı "5 puan) bir ölçektir. Ölçekte ters kodlanması gereken ifade yoktur. Ölçekten alınan toplam ham puan 30-150 arasında değişmekte, ayrıca değerlendirme için bir hesaplama yapılarak ölçek puanı elde edilmektedir. Hesaplama, "Bireyin Ölçek Puanı=Ölçekten Alınan 
Yücel, U., Ünal, I., Özdemir, T., Koyuncu, M. ve Çakmak, N. Medical Sciences (NWSAMS), 1B0056, 2018; 13(4): 94-104.

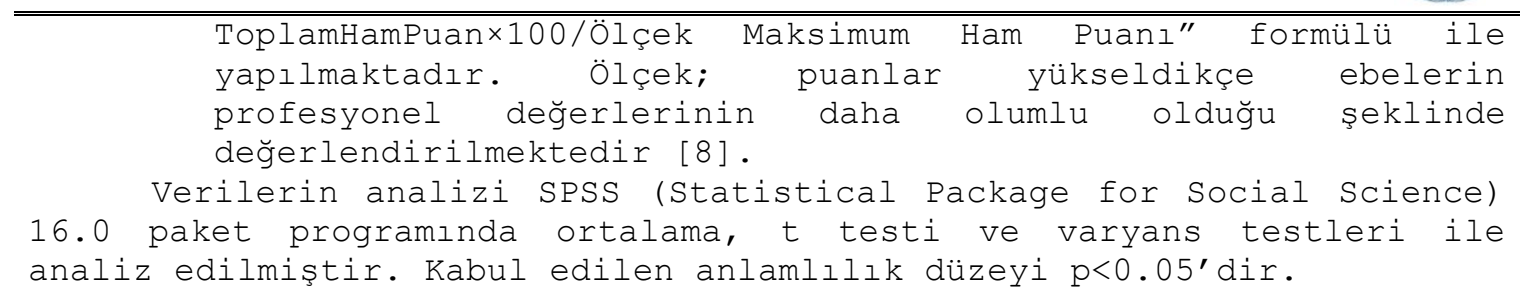

\section{BULGULAR (RESULTS)}

Öğrencilerin \%55.2'si 18-20 yaş arasında olup, \%67.9'u oranında ağırlıklı olarak Anadolu-Fen Lisesi, ⒚4'ü Genel-Düz Lise mezunudur. Katılımcıların \%56.8' in annesi, \%40.4'ünün babası ilkokul mezunudur (Tablo 1).

Tablo 1. Öğrencilere ait bazı özellikler

(Table 1. Some characteristics of the students)

\begin{tabular}{|c|c|c|}
\hline Değişkenler & Sayı (n) & Yüzde (응 \\
\hline \multicolumn{3}{|l|}{ Sinıf } \\
\hline 1.Sinıf & 85 & 26.2 \\
\hline 2. Sinıf & 83 & 25.6 \\
\hline 3. Sinıf & 86 & 26.6 \\
\hline 4. Sinıf & 70 & 21.6 \\
\hline \multicolumn{3}{|l|}{ Yaş } \\
\hline $18-20$ Yaş & 179 & 55.3 \\
\hline 21-23 Yaş & 131 & 40.4 \\
\hline 24 Yaş ve Üzeri & 14 & 4.3 \\
\hline \multicolumn{3}{|l|}{ Mezun Olunan Lise } \\
\hline Anadolu-Fen Lisesi & 220 & 67.9 \\
\hline Genel-Düz Lise & 63 & 19.4 \\
\hline Sağlık Meslek Lisesi & 20 & 6.2 \\
\hline Öğretmen Lisesi & 12 & 3.7 \\
\hline Diğer & 9 & 2.8 \\
\hline \multicolumn{3}{|l|}{ Annenin Eğitim Durumu } \\
\hline Okur-Yazar Değil & 19 & 5.9 \\
\hline İlkokul & 184 & 56.8 \\
\hline Ortaokul & 66 & 20.4 \\
\hline Lise & 45 & 13.9 \\
\hline Üniversite ve Üzeri & 10 & 3.1 \\
\hline \multicolumn{3}{|l|}{ Babanın Eğitim Durumu } \\
\hline Okur-Yazar Değil & 4 & 1.2 \\
\hline İlkokul & 131 & 40.4 \\
\hline Ortaokul & 70 & 21.6 \\
\hline Lise & 74 & 22.8 \\
\hline Üniversite ve Üzeri & 45 & 13.9 \\
\hline Toplam & 324 & 100.0 \\
\hline
\end{tabular}

Ebelik bölümü, öğrencilerin üniversite tercih sıralamasında 25.0'inin ilk tercihi iken, 54.0'ıdört ve üzerindeki sıralamada yer almıştır. Öğrencilerin o57.7'sinin sağlık mensubu bir yakını vardır ve öğrencilerin 67.6'sı bölümü isteyerek seçmiştir. Öğrencilerin mesleği seçme nedenleri ve kendine uygun bulma durumları incelendiğinde ○49.4'ün kendi isteğiyle, 29.9'unun ise iş bulma kolaylığı nedeniyle ebelik bölümünü tercih ettikleri görülmüştür. Ebelik mesleğinin kendileri için uygun olduğunu ifade eden öğrencilerin oranı 63.0'dır. Mesleki eğitime başlamadan önce öğrencilerin sadece 으.3'ü ebelik ile ilgili olumlu düşünceye sahipken, bu oranın eğitiminden sonra \%64, 8'e yükselmiştir. Öğrencilerin o77.2'si mezuniyet sonrası ebelik yapacaklarını belirtirken, ⒙2'si akademisyen olmayı planlamaktadır. Mezuniyet sonrası ebelik yapmak isteyen öğrencilerden (n=250), 
Yücel, U., Ünal, I., Özdemir, T., Koyuncu, M. ve Çakmak, N. Medical Sciences (NWSAMS), 1B0056, 2018; 13(4): 94-104.

o52.0'si ikinci basamakta, 46.8'i de birinci basamakta çalışmayı düşünmektedir (Tablo 2).

Tablo 2. Öğrencilerin bölümle ilgili görüşlerine ait bazı özellikler

(Table 2. Some features of students' opinions about the department)

\begin{tabular}{|c|c|c|}
\hline Değişkenler & Sayı $(n)$ & Yüzde (\%) \\
\hline \multicolumn{3}{|l|}{ Bölüm Tercih Sırası } \\
\hline 1. Tercih & 81 & 25.0 \\
\hline 2. Tercih & 32 & 9.9 \\
\hline 3. Tercih & 36 & 11.1 \\
\hline 4. Tercih ve Üzeri & 175 & 54.0 \\
\hline \multicolumn{3}{|c|}{ Bölüme İsteyerek Gelme } \\
\hline Evet & 219 & 67.6 \\
\hline Hayır & 105 & 32.4 \\
\hline \multicolumn{3}{|c|}{ Sağlık Mensubu Yakını Olma Durumu } \\
\hline Evet & 187 & 57.7 \\
\hline Hayır & 137 & 42.3 \\
\hline \multicolumn{3}{|l|}{ Mesleği Seçme Nedeni } \\
\hline Kendi İsteğim & 160 & 49.4 \\
\hline Aile $\dot{I} s t e g ̆ i$ & 49 & 15.1 \\
\hline Kolay İş Bulmak & 97 & 29.9 \\
\hline Diğer & 18 & 5.6 \\
\hline \multicolumn{3}{|c|}{ Ebelik Mesleğini Kendine Uygun Bulma } \\
\hline Evet & 204 & 63.0 \\
\hline Hayır & 15 & 4.6 \\
\hline Kararsızım & 105 & 32.4 \\
\hline \multicolumn{3}{|c|}{ Eğitimden Önce Meslek İle İlgili Düşüncesi } \\
\hline Olumlu & 121 & 37.3 \\
\hline Kısmen Olumlu & 162 & 50.0 \\
\hline Olumsuz & 41 & 12.7 \\
\hline \multicolumn{3}{|c|}{ Eğitimden Sonra Meslek İle İlgili Düşüncesi } \\
\hline Olumlu & 210 & 64.8 \\
\hline Kısmen Olumlu & 99 & 30.6 \\
\hline Olumsuz & 15 & 4.6 \\
\hline \multicolumn{3}{|c|}{ Mezuniyet Sonrası Çalışma Planı } \\
\hline Ebelik Yapmak & 250 & 77.2 \\
\hline Akademisyen Olmak & 59 & 18.2 \\
\hline Diğer & 15 & 4.6 \\
\hline \multicolumn{3}{|c|}{ Çalışmak istenilen kurum* $(n=250)$} \\
\hline Birinci Basamak & 117 & 46.8 \\
\hline İkinci Basamak & 130 & 52.0 \\
\hline Diğer & 3 & 1.2 \\
\hline Toplam & 324 & 100.0 \\
\hline
\end{tabular}

*Ebe olarak çalışmak istediğini belirten öğrencilerin çalışmak istedikleri sağlık kurumlara göre dağılımı verilmiştir

Tablo 3'te öğrencilerin eğitimleri sırasında uygulamalı derslere katılma durumları gösterilmiştir. Öğrencilerden ( $=243)$, 66.4'ü doğumhanede, 이.5'i aile sağlığı merkezinde uygulama yapmış, 25.0' sahada ev ziyaretine katılmıştır. 
Yücel, U., Ünal, 亡., Özdemir, T., Koyuncu, M. ve Çakmak, N. Medical Sciences (NWSAMS), 1B0056, 2018; 13(4): 94-104.

Tablo 3. Öğrencilerin uygulamalı derslere katılım durumları

(Table 3. Participation of students in practical lessons)

\begin{tabular}{|l|c|c|}
\hline Değişkenler & Sayı (n) & Yüzde (\%) \\
\hline Herhangi Bir Sağlık Kurumdan Uygulamaya Çıkma \\
\hline Evet & 243 & 75.0 \\
\hline Hayır & 81 & 25.0 \\
\hline Doğumhanede Uygulamaya Çıkma & 215 & 66.4 \\
\hline Evet & 109 & 33.6 \\
\hline Hayır & 102 & 31.5 \\
\hline Aile Sağlığı Merkezi'nde Uygulamaya Çıkma \\
\hline Evet & 222 & 68.5 \\
\hline Hayır & 81 & 25.0 \\
\hline Sahada ev Ziyaretine Katılma & 243 & 75.0 \\
\hline Evet & 324 & 100.0 \\
\hline Hayır
\end{tabular}

Öğrencilerin profesyonel değer algıları puan ortalaması $87.2 \pm 1.0$ (min:60-max:100)'dir (Tablo 4).

Tablo 4. Ebelik Öğrencilerinin profesyonel değer algısı

(Table 4. Professional perception of midwifery students)

\begin{tabular}{|c|c|c|c|c|}
\hline & $\mathrm{n}$ & Minumum Puan & Maksimum Puan & Ort \pm Sd \\
\hline EPDÖ Puanı & 324 & 60.00 & 100.00 & $87.2 \pm 1.0$ \\
\hline
\end{tabular}

Tablo 5'te öğrencilerin bazı özellikleri ile EPDÖ puan ortalamaları arasındaki ilişki gösterilmiştir. Öğrencilerin, mezun olduğu lise, ebeveynlerin eğitim durumu, üniversite tercih sıralamasında bölüm tercih sırası, bölüme isteyerek gelme durumu, sağlık mensubu yakının olma durumu, mesleği seçme nedeni, ebelik mesleğini kendine uygun bulma durumu, eğitim başladıktan sonra meslek ile ilgili düşüncesi, mezuniyet sonrası çalışmak istediği alan ve sahada ev ziyaretlerine katılma durumları ile EPDÖ puan ortalaması arasında anlamlı fark yoktur.

Araştırma grubunun, okuduğu sınıf, herhangi bir sağlık kurumunda, doğumhanede ve aile sağlığı merkezlerinde uygulamaya çıkma durumları ile EPDÖ puan ortalamaları arasında anlamlı bir fark bulunmuştur. İkinci, üçüncü ve dördüncü sınıfta okuyan öğrencilerin, birinci sınıf öğrencilerine göre ( $\mathrm{p}=0.00)$, ebelik eğitimine başladıktan sonra meslek ile ilgili olumlu düşüncesi olanların, kısmen olumlu veya olumsuz olanlara göre ( $\mathrm{p}=0.06)$, EPDÖ puan ortalamaları daha yüksektir. Öğrencilerin uygulamalı derslere katılma durumları ile EPDÖ puanları arasındaki ilişki incelendiğinde; herhangi bir sağlık kurumunda $(p=0.00)$, doğumhanede $(p=0.00)$ ve Aile Sağlığı Merkezi'nde ( $\mathrm{p}=0.04)$ uygulamaya çıkanların, çıkmayanlara göre EPDÖ puan ortalamalarının daha yüksek olduğu belirlenmiştir. 
Yücel, U., Ünal, 亡., Özdemir, T., Koyuncu, M. ve Çakmak, N. Medical Sciences (NWSAMS), 1B0056, 2018; 13(4): 94-104.

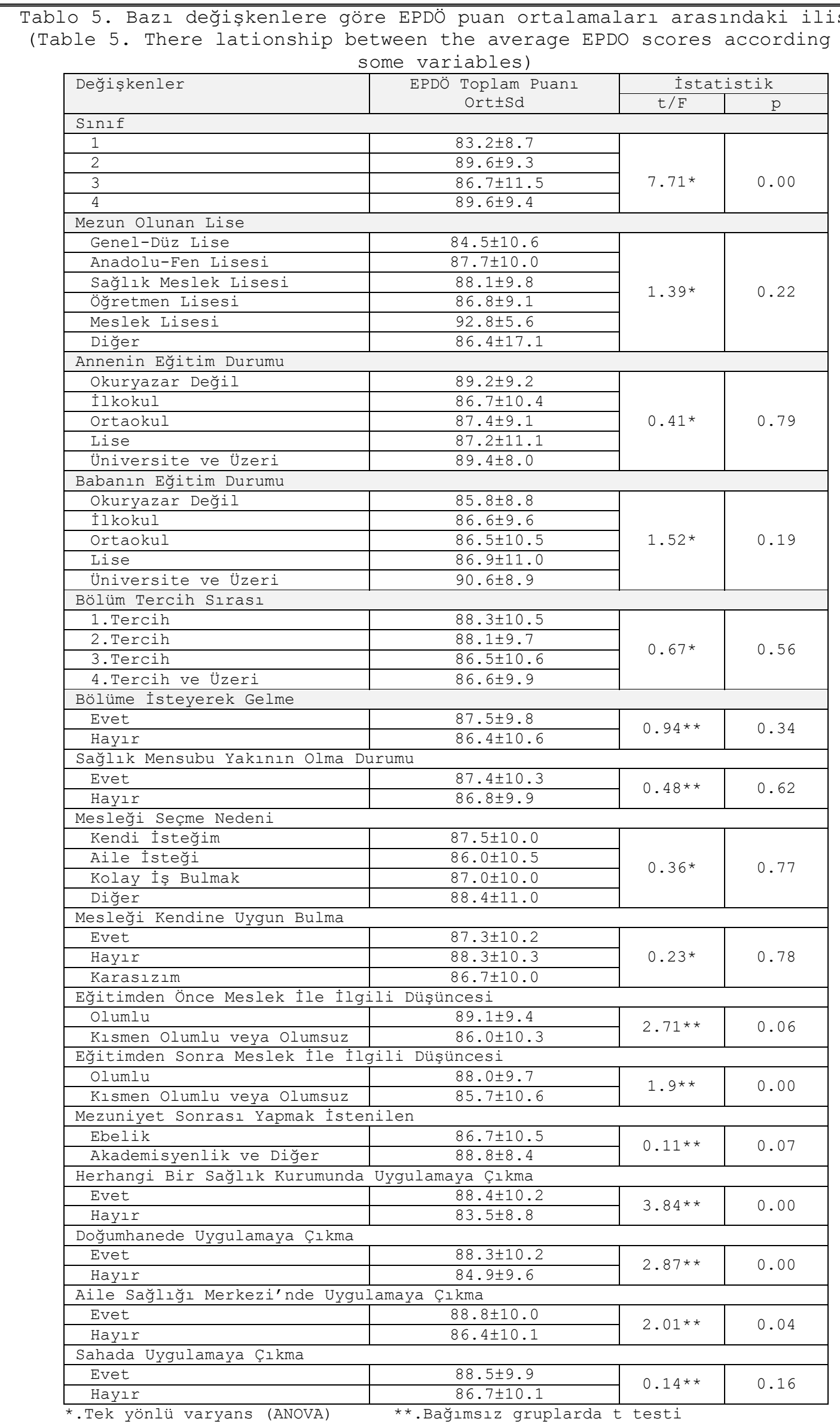


Yücel, U., Ünal, 亡., Özdemir, T., Koyuncu, M. ve Çakmak, N. Medical Sciences (NWSAMS), 1B0056, 2018; 13(4): 94-104.

\section{TARTIŞMA (DISCUSSION)}

Bu araştırmada, ebelik öğrencilerinin mesleklerine ait bazı özellikleri tanımlanmış, bu özelliklerin profesyonel değer ile ilişkisi incelenmiştir. Çalışmada ayrıca, öğrencilerin okumakta oldukları sınıf ve uygulamaya çıkma durumlarının profesyonel değer algıları üzerindeki etkisi değerlendirilmiştir. Ebelik bölümünde okuyan öğrencilerin yarısından fazlasının ebeveynleri düşük eğitimlidir. Farklı üniversitelerin ebelik bölümünde yapılan çalışmalarda da sonuçlar benzer şekildedir [5, 9 ve 14]. Ebelik ve hemşirelik bölümlerinde okuyan öğrencilerin ebeveynlerinin eğitim düzeyinin düşük olduğu pek çok çalışmada bildirilmiştir [15 ve 19]. Ebelik öğrencilerinin bölümü tercih etmesindeki en belirleyici faktör iş bulma kolaylığı (\%29.9) olmakla birlikte, bu oran farklı çalışmalarda bildirilen orandan daha düşüktür (\%32.3-89.0) [3, 5, 9, 13, 20 ve 21]. Bu fark araştırma grubunun özelliklerinden kaynaklanabileceği gibi, araştırmalarda mesleği tercih etme sorusuna yönelik yanıtların farklı gruplandırılmasının da etkili olabileceği düşünülmüştür.

Öğrencilerin yarısı kendi isteği ile bölümü tercih etmişlerdir. Ebelik bölümünde yapılan diğer çalışmalar, öğrencilerin mesleklerini isteyerek seçtiklerini göstermektedir $[3,5,7,9,20$ ve 21]. Katılımcıların 2/3'si mesleği kendine uygun bulmaktadır. Farklı üniversitelerde yapılan çalışmalarda da öğrenciler, ebeliği kendine uygun bir meslek olarak tanımlamıştır [3, 7 ve 22]. Yılmaz (2014)'ın çalışmasında ebeler (59.1), ebelik mesleğini kişilik özelliklerine uygun bulduklarını belirtmişlerdir [23]. Mesleki eğitim, teorik bilgi ve uygulama becerisinin kazanılmasının yanı sıra mesleki bakış açısının geliştiği ve meslek felsefesinin edinildiği bir dönemdir [3 ve 24]. Literatür incelendiğinde çalışmamızda da olduğu gibi öğrencilerin ebelik ile ilgili düşüncelerinin, eğitim aldıktan sonra eğitim almadan önceki döneme göre olumlu yönde geliştiği görülmektedir $[3,5,9,21$ ve 25]. Çalışmada öğrencilerin çoğunluğu mezuniyet sonrası ebelik yapmak isterken, bir kısmı da akademisyen olmak istemektedir. Ebe olarak çalışmak isteyenlerin yarısı birinci basamakta, diğer yarısı da ikinci basamak sağlık kurumlarında çalışmayı düşünmektedir. Yücel ve ark. (2017)'nın aynı kurumda daha önceki yıllarda yaptıkları çalışmasında da mezuniyet sonrası ebelik yapmak isteyen ve akademisyenlik düşünenlerin oranları çalışmamızla benzerdir [24].

Farklı üniversitelerin ebelik bölümünde yapılan diğer çalışmalarda, akademisyen olmak isteyenlerin oranlarının daha düşük olduğu görülmüştür [3,5 ve 7]. Koçak ve ark. (2017)'nın yaptıkları çalışmada, araştırmanın yapıldığı ebelik bölümündeki akademik personel sayısının, Türkiye'deki ebelik bölümleri arasında niceliksel açıdan en iyi durumda olduğu bildirilmiştir [26]. Akademisyen sayısının yanı sıra, bu kurumda yüksek lisans ve doktora programlarının yürütülüyor olması öğrencileri akademisyenliğe yönelten, motive edici faktörler olabileceği düşünülmüştür. Ebelik mesleki eğitiminin, üniversite düzeyine çıkması ve lisansüstü eğitimlerin açılması ile birlikte profesyonelleşme süreci hızlanmıştır [26 ve 28]. Ebelikte profesyonelleşmeye olan ilgi ülkemizde son yıllarda artmıştır [27 ve 28]. Katılımcıların profesyonel değer algıları incelendiğinde,

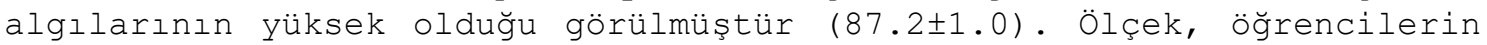
profesyonel değerlerini belirlemek amacıyla 2018 yılında geliştirildiğinden, bu sonuç aynı ölçeği kullanan literatür ile karşılaştırılamamıştır. Erol ve ark. (2018) ebelik öğrencilerinin mesleki profesyonel tutumlarını ölçmek için yaptıkları çalışmada "Öğrenci Hemşirelere Yönelik Profesyonellik Tutum Ölçeği"ni kullanmışlardır. Çalışmadan elde ettikleri puan ortalaması 140 tam puan üzerinden 104.66 17.61'dir [29]. Pınar ve ark. (2013) ise, ebelik 
Yücel, U., Ünal, 亡., Özdemir, T., Koyuncu, M. ve Çakmak, N. Medical Sciences (NWSAMS), 1B0056, 2018; 13(4): 94-104.

öğrencilerinin mesleki profesyonelliklerini belirlemek için "Meslekte Profesyonel Tutum Envanteri (MPTE)"ni kullanmışlardır. Ölçekten 160 tam puan üzerinden $144.99 \pm 14.00$ puan elde edilen çalışmada, ebelik öğrencilerinin profesyonel tutumları benzer şekilde yüksek olarak yorumlanmıştır [3]. Öğrencilerin mesleki uygulama deneyimi ile profesyonel değer algıları gelişir [23]. Çalışmamızda birinci sınıf ebelik öğrencileri ile üst sınıflar arasında profesyonel değer algısı açısından fark vardır. Benzer şekilde Pınar (2014)' ın çalışmasında da profesyonel değerlerden olan mesleksel güdülenme ile sınıf düzeyi arasında fark saptanmıştır [29]. Birinci sınıf öğrencilerini mesleki yaşama hazırlayan Temel ìlke ve Uygulamalar dersi hasta merkezli bakımı amaçlar [37]. Sınıf düzeyi yükseldikçe mesleğe özel uzmanlık bilgisini içeren dersler ağırlık kazanmaktadır. Teorik ve uygulamayı kapsayan bu beceri profesyonelliğin gelişmesini sağlar [31 ve 38]. Sağlık bölümlerinde okuyan öğrencilerle yapılan çalışmalarda, uygulamalı eğitimlerden sonra öğrencilerin mesleklerine karşı tutumlarının olumlu yönde geliştiği ve profesyonel değerlerinin yükseldiği bildirilmiştir [39 ve 40].

Mesleki rol ve sorumluluklarl pratik yaparak yerine getirme flrsatı veren klinik ve saha uygulama alanları; ebelikte mesleki becerilerin geliştirilmesinde ve mesleki profesyonellikte önemlidir [21, 34 ve 35]. Çalışmamızda bağımsız rollerini uygulama fırsatı buldukları doğumhane ve aile sağlığı merkezinde uygulamaya çıkan üst sınıftaki öğrencilerin, herhangi bir klinikte uygulamaya çıkan birinci sınıf öğrencilerine göre, profesyonel değer algılarının daha yüksek olduğu görülmüştür $(\mathrm{p}<0.05)$. Sağlık bölümlerinde okuyan öğrencilerle yapılan çalışmalarda, sağlık kurumlarında yapılan uygulamanın öğrencilerin empatik becerilerini, motivasyonlarını, mesleğe olan sevgilerini, eleştirel düşünme becerilerini ve buna bağlı olarak profesyonel meslek yaşantılarındaki başarılarını, mesleki sosyalizasyonlarını arttırdığı ve kendilerini profesyonel (yeterli, güvenli ve mesleğe hazır) hissetmelerine yardımcı olduğu bildirilmiştir [20, 32, 33, 36 ve 39]. Meslek mensuplarının, mesleki aidiyet ve profesyonel değerleri kazanmaları, profesyonel rollerini yerine getirebilmelerinde doğru şekilde istihdam edilmeleri en temel koşuldur [24 ve 30]. Ülkemizde yasal bazı mevzuatlara dayanılarak, ebelerin bir kısmı hemşirelik hizmetlerini yürütmektedir. Yataklı Tedavi Kurumları İşletme Yönetmeliği’nin (1983) 133. maddesine göre, ebeler ana-çocuk sağlığı, doğum ve aile planlaması gibi asli görevlerinin yanı sıra hemşirelik hizmetlerini yapmakla yükümlü tutulmuştur [40].

Yücel ve ark. (2017)'nın ve Kayacı (2006)'nın yaptıkları çalışmalarda ebelik öğrencilerinin mesleklerine uygun sağlık kurumlarında ve birimlerinde çalışmak istedikleri bildirilmiştir [9 ve 24]. Mesleki rollerini yerine getiremedikleri alanlarda istihdam edilen ebelerin profesyonel tutumlarının, kendi mesleğini uygulayabilen kurumlarda ve birimlerde çalışan ebelere göre daha düşük olduğu bildirilmiştir [6]. Mezuniyet öncesi mesleğe özgü uygulama alanlarının, öğrencilere profesyonel değerler kazandırması beklenen bir sonuçtur. Bununla birlikte, mezuniyetten sonra profesyonel değerlerin gelişmesinin sağlanmasında, doğru istihdam oldukça önemlidir. Okuyan ve ark. (2018)'nın çalışmasında kendi alanlarında istihdam edilmeyen ebelerin profesyonel tutumlarının, aile sağlığı merkezinde çalışan ebelere göre, daha düşük olduğu bildirilmiştir [6] .

\section{SONUÇ VE ÖNERILER (CONCLUSIONS AND RECOMMENDATIONS)}

Öğrenciler bölümü kendi isteği ile, iş bulma kolaylığı ve ebeliği kendine uygun bulmaları nedeniyle tercih etmişlerdir. Profesyonel değer algıları yüksektir ve sınıf düzeyi, ebelik eğitiminden sonraki mesleki düşünce, herhangi bir sağlık kurumunda uygulamaya çıkma, 
Yücel, U., Ünal, 亡., Özdemir, T., Koyuncu, M. ve Çakmak, N. Medical Sciences (NWSAMS), 1B0056, 2018; 13(4): 94-104.

\begin{tabular}{l}
\hline doğumhane ve aile sağlığı merkezinde uygulamaya çıkma durumları ebelik \\
bölümü öğrencilerinin profesyonel değer algılarını yükselten \\
faktörlerdir. Ebelerin mezuniyet öncesi ve sonrası profesyonel \\
değerlerini belirlemeye yönelik veri toplama araçlarının \\
geliştirilmesi ve alanda uygulanmasına gereksinim vardır. Yapılacak \\
çalışmalardan elde edilecek bilgiler doğrultusunda, profesyonel \\
değerleri etkileyen faktörler analiz edilmelidir. Bu bilgiler, \\
profesyonel değerleri geliştirme stratejilerinde kullanılmalıdır.
\end{tabular}

\section{KAYNAKLAR (REFERENCES)}

1. Ersoy, N., Özcan, M. ve Ergin, A., (2015). Ebelik Uygulamalarında Profesyonel Etik. Nobel Yayın, 2015, Ankara.

2. Saydam, B.K., (2015). Profesyonel Bir Meslek Olarak Türkiye'de Ebelik. Sağlık ve Toplum, Cilt:25, Sayı:1, ss:3-9.

3. Pınar, Ş.E., Cesur, B., Duran, Ö., Güler, E., Üstün, Z. ve Abak, G., (2013). Ebelik Öğrencilerinin Mesleki Profesyonellikleri ve Etkileyen Etmenlerin İncelenmesi. Fırat Sağlık Hizmetleri Dergisi, Cilt:8, Sayı:23, ss:19-37.

4. Dinç, A., Cangöl, E. ve Söğüt, S., (2017). Ebelik Öğrencilerinin Mesleki Tercih Hakkında Düşünceleri. Cumhuriyet Üniv. Sağ. Bil. Enst. Derg., Cilt:2, Sayı:2, ss:15-23.

5. Yurtsal, Z.B., Biçer, S., Duran, Ö., Şahin, A., Arslan, M. ve Yavrucu, Ö., (2014). Sağlık Bilimleri Fakültesi Ebelik 1. ve 4. Sınıf Öğrencilerinin Mesleğe İlişkin Görüşlerinin Belirlenmesi. Erciyes Üniversitesi Sağlık Bilimleri Fakültesi Dergisi, Cilt:2, Sayı:2, ss:15-25.

6. Okuyan, Y.Ç. ve ark., (2018). Ebelerin Meslekte Profesyonel Tutumlarının İncelenmesi, 5. Uluslararası \& 9. Ulusal Ebelik Öğrenci Kongresi, Amasya.

7. Kartal, Y.A. ve Yazıcı, S., (2017). Ebelik Öğrencilerinin İlk Klinik Deneyim Başlangıcı ve Sonunda Anksiyete ve Stres Düzeylerinin Belirlenmesi. HSP, Cilt:4, Sayı:3, ss:190-195.

8. Meydan, Ş.D. ve Kaya, N., (2018). Ebelerin Profesyonel Değerleri Ölçeğinin Geliştirilmesi. Sağlık Bilimleri ve Meslekleri Dergisi. Cilt:5, Sayı:2, ss:129-138.

9. Kayacı, S., (2006). Sağlık Yüksekokulları Ebelik Bölümü Öğrencilerinin Ebelik Mesleği Hakkındaki görüşlerini etkileyen faktörlerin incelenmesi. Dokuz Eylül Üniversitesi Sağlık Bilimleri Enstitüsü, Hemşirelik Anabilim Dalı Doğum ve Kadın Hastalıkları Hemşireliği Yüksek Lisans Tezi.

10. Bozkurt, Ö.D., Daşıkan, Z., Kavlak, O. ve Şirin, A., (2013). Ebelik Öğrencilerinin Gebelikte Şiddet Konusundaki Bilgi, Görüş Ve Mesleki Tutumlarının Belirlenmesi. Balıkesir Sağlık Bilimleri Dergisi, Cilt:2, Sayı:2, ss:99-107.

11. Pınar, Ş.E., Aksoy, Ö.D., Cesur, B. ve Dağlar, G., (2017). Ebelik Öğrencilerinin Eleştirel Düşünme Eğilimleri ve İletişim Becerileri: Yıllara Göre İzlem Çalışması. Journal of Human Sciences, Cilt:14, Sayl:2, ss:1117-1128.

12. Tezel, A. ve Arslan, S., (2002). Erzurum Sağlık Yüksekokulu 1. Sınıf Öğrencilerinin Mesleklerini Seçmeye Ve Mesleğe ìlişkin Görüşleri. Atatürk Üniversitesi Hemşirelik Yüksekokulu Dergisi, Cilt:5, Sayı:2, ss:39-45.

13. Erkal, İ.S., Yalçın, A.S. ve Sancar, B., (2012). Ankara Üniversitesi Sağlık Bilimleri Fakültesi Öğrencilerinin Ebelik Ve Hemşirelik Bölümlerini Seçme Nedenleri. Ankara Sağlık Bilimleri Dergisi, ss:73-90.

14. Yıldırım, F., Çelik, P., Özmen, C., Erol, S., Üst, Z.D. ve Özkan, H., (2014). Ebelik Bölümü Öğrencilerinin Ebelik Mesleğinde Erkeklerin Yer Almasına İlişkin Görüşleri. Gümüşhane 
Yücel, U., Ünal, 亡., Özdemir, T., Koyuncu, M. ve Çakmak, N. Medical Sciences (NWSAMS), 1B0056, 2018; 13(4): 94-104.

Üniversitesi Sağlık Bilimleri Dergisi, Cilt:3, Sayı:1, ss:646655 .

15. Güvenç, G., Akyüz, A. ve Seven, M., (2012). Hemşirelik Yüksek Okulu Öğrencilerinin Humanpapilloma Virüs Enfeksiyonu ve Aşıları İle İlgili Bilgi ve Tutumlarının Belirlenmesi. Gülhane Tıp Dergisi, Cilt:54, ss:104-110.

16. Andsoy, I., Güngör, T. ve Bayburtluoğlu, T., (2012). Karabük Üniversitesi Sağlık Yüksekokulu Öğrencilerinin Hemşireliği Tercih Etme Nedenleri ve Mesleğin Geleceği İle İlgili Görüşleri. Balıkesir Sağlık Bilimleri Dergisi, Cilt:1, Sayı:1, ss:124-130.

17. Özveren, H., Gülnar, E. ve Özden, D., (2017). Hemşirelik Öğrencilerinin Meslek Seçimini Etkileyen Faktörlerin Belirlenmesi. Turk J Clin Lab, Cilt:8, Sayı:2, ss:57-64.

18. Şirin, A., Öztürk, R., Bezci, G., Çakar, G. ve Çoban, A., (2008). Hemşirelik Öğrencilerinin Meslek Seçimi ve Mesleği Uygulamaya Yönelik Görüşleri, Dirim Tıp Gazetesi, Cilt:83, ss: $69-75$.

19. Duran, S., Karadaş, A. ve Kaynak S., (2017). Hemşirelik Öğrencilerinin Olumsuz Otomatik Düşünceleri ve Akademik Başarıları Arasındaki İlişki. Kocaeli Medical Journal, Cilt:6, Sayı:2, ss:30-37.

20. Orak, S., Orhan, H., Ağırman, Ö. ve Özgürce, B., (2008). Hemşirelik Ebelik Eğitiminde Süleyman Demirel Üniversitesi Örneği: Isparta Sağlık Yüksekokulu İntörn Öğrencilerinin Klinik Sahada Entegre Uygulaması İle İlgili Bilgi ve Tutumları. Süleyman Demirel Üniversitesi Tıp Fakültesi Dergisi, Cilt:15, Sayı:3, ss:11-16.

21. Bilgin, Z., Özkan, H.A. ve Baş, M., (2016). Ebelik Öğrencilerinde Güdülenme Düzeyinin Klinik Uygulama Beklentisine Etkisi. Online Türk Sağlık Bilimleri Dergisi, Cilt:1, Sayı:2, ss: $38-53$.

22. Pınar, Ş.E., Yıldırım, G., Duran, Ö., Cesur, B., Üstün, Z. ve Güler, E., (2014). Ana Çocuk Sağlığı Hizmetlerinde Kilit Rolde Olan Ebe Adaylarının Güdülenmeleri Yeterli Mi? Bir Anket Çalışması. Hemşirelikte Eğitim ve Araştırma Dergisi, Cilt:11, Sayı:3, ss:22-31.

23. Yılmaz, F.T., Şen, H.T. ve Demirkaya, F., (2014). Hemşirelerin ve Ebelerin Mesleklerini Algılama Biçimleri ve Gelecekten Beklentileri. Sağlık ve Hemşirelik Yönetimi Dergisi, Cilt:3, Sayı:1, ss:130-139.

24. Yücel, U., Oran, N.T. ve Yüksel, E., (2017). Ebelik Öğrencilerinin Meslek İle İlgili Görüşlerinin ve Mezuniyet Sonrası Çalışmak İstedikleri Kurumların Değerlendirilmesi, GÜSBD, Cilt:6, Sayı:4, ss:69-76.

25. Ay, F., Keçe, M., Inci, İ., Alkan, N. ve Acar, A., (2017). Ebelik Öğrencilerinin Meslek Algıları. 4. Uluslararası\& 8.Ulusal Ebelik Öğrenci Kongresi, İstanbul.

26. Koçak, Y.Ç., Can, H.Ö., Yücel, U., Demirelöz, M. ve Turfan E.Ç., (2017). Türkiye' de Ebelik Bölümlerinin Akademik ve Fiziki Profili. HSP, Cilt:4, Sayı:2, ss:88-97.

27. Güner, S., Yurdakul, M. ve Yetim, N., (2015). Türkiye'de Ebelik Mesleğinin Sorunlarına Akademik Bakışı Yansıtan Nitel Bir Çalışma. Yükseköğretim ve Bilim Dergisi, Cilt:5, Sayı:1, ss:8087.

28. Yücel, U., Ekşioğlu, A., Demirelöz, M., Akmeşe, Z.B., Koçak, Y.Ç. ve Soğukpınar, N., (2013). Türkiye'de Ebelik Lisansüstü Eğitim Profilinin İncelenmesi. International Journal of Human Sciences, Cilt:10, Sayı:1, ss:1342-1354.

29. Erol, F. ve ark., (2018). Ebelik Öğrencilerinin Mesleki Profesyonel Tutumları ve Etkileyen Faktörlerin Íncelenmesi, 
Sözel Bildiri, 5. Uluslararası \& 9. Ulusal Ebelik Öğrenci

Kongresi, Amasya.

30. Çalışkan, T. ve Akgöz, S., (2005). Sağlık Yüksek Okulu Öğrencilerini Mesleki Yaşama Hazırlamada Yıl İçi ve Yaz Stajlarının Katkısı. Uludağ Üniversitesi Tıp Fakültesi Dergisi, Cilt:31, Sayı:1, ss:9-13.

31. Adıgüzel, O., Tanrıverdi, H. ve Sönmez, D.Ö., (2011). Mesleki Profesyonellik ve Bir Meslek Mensupları Olarak Hemşireler Örneği. Yönetim Bilimleri Dergisi, Cilt:9, ss:239-59.

32. Alparslan, Ö., (2017). Ebelik ve Hemşirelik Öğrencileri Gözüyle Klinik Uygulamalar, Okul-Hastane İşbirliği. J ContempMed, Cilt:7, Sayı:4, ss:365-372.

33. Tosun, N., ve ark., (2008). Hemşirelik Yüksekokulu Öğrencilerinin İntörn Eğitim Programından Beklentileri ìle Program Sonunda Kazanım ve Önerilerinin Değerlendirilmesi. Gülhane Tıp Dergisi, Cilt:50, ss:164-171.

34. Dikmen, Y.D., Yönder, M., Yorgun, S., Usta, Y.Y., Umur, S. ve Aytekin, A., (2014). Hemşirelerin Profesyonel Tutumları İle Bunu Etkileyen Faktörlerin İncelenmesi, Anadolu Hemşirelik ve Sağlık Bilimleri Dergisi, Cilt:17, Sayı:3, ss:158-164.

35. Wynd, C.A., (2003). Current Factors Contributing to Professionalism in Nursing. Journal of Professional Nursing Cilt:19, Sayi:5; ss:251-61.

36. Cevahir, R., Çınar, N., Sözeri, C., Şahin, S. ve Kuğuoğlu, S., (2018). Ebelik Öğrencilerinin Devam Ettikleri Sınıflara Göre Empatik Becerilerinin Değerlendirilmesi. Fırat Sağlık Hizmetleri Dergisi, Cilt:3, Sayı:7, ss:3-15.

37. Şirin, A., Kavlak, O. ve Ertem, G., (2003). Doğumhane Stajına Çıkan Öğrencilerin Durumluk-Sürekli Kaygı Düzeylerinin Belirlenmesi. C.Ü. Hemşirelik Yüksekokulu Dergisi. Cilt:7, Sayı:1, ss:27-32.

38. Bayar, K., Çadır, G. ve Bayar, B., (2009). Hemşirelik Öğrencilerinin Klinik Uygulamaya Yönelik Düşünce Ve Kaygı Düzeylerinin Belirlenmesi. TAF Prev Med Bull, Cilt:8, Sayı:1, ss: $37-42$.

39. Küçükgüçlü, Ö. ve Kanbay, Y., (2011). Hemşirelik Öğrencilerinin Eleştirel Düşünme Eğilimleri İle Klinik Başarıları Arasındaki İişkinin Incelenmesi. Anadolu hemşirelik ve Sağlık Bilimleri Dergisi, Cilt:14, Sayı:3, ss:21-25.

40. TC. Sağlık Bakanlığı. Yataklı tedavi kurumları işletme yönetmeliği, 1983. dosyaism.saglik.gov.tr, (Erişim Tarihi: $18.09 .2018)$. 